\title{
Sociedade Civil e Hipertermia Maligna - Sempre
}

\section{Viva}

Non - Governamental Groups and MH - Sempre Viva Group

\section{Rogerio Firme}

Tópicos abordados:

1. O que é a Sempreviva?

2. Por que Sempreviva?

3. Como foi constituída?

4. Em que consiste seu trabalho?

5. Ações políticas da Sempreviva

6. Conquistas da Sempreviva

7. Ações atuais da Sempreviva

8. Precisamos de parcerias para poder continuar nosso trabalho. 